\title{
Drugs for alcohol dependence
}

\author{
Julia Sinclair
}

Julia Sinclair MB BS MRCPsych DPhil is Associate Professor of Psychiatry, University of Southampton and Honorary Consultant in Alcohol Liaison, University Hospital Southampton, UK. Her primary research aim is to conduct clinically relevant research in patients with alcohol use disorders, specifically to investigate how biological, psychological and social mechanisms interact in this group, and their impact on clinical outcomes in terms of prevention, engagement and response to treatment. Competing interests: until 2015, she was part of the international advisory board for Lundbeck A/S for nalmefene.

\begin{abstract}
There is good evidence for the use of pharmacological treatments to improve outcomes in patients with alcohol use disorders (AUD). The management of acute withdrawal should include a high risk of suspicion for Wernicke-Korsakoff Syndrome, necessitating treatment with parenteral high-potency B vitamins (Pabrinex®). Benzodiazepines in reducing doses should be used in conjunction with a continuing treatment plan after detox (detox). The relapse prevention medications acamprosate and naltrexone should be considered in all patients with moderate to severe alcohol dependence wishing to maintain abstinence. Disulfiram can be considered as a second-line treatment, but should be initiated by a specialist. Nalmefene has been shown to be effective in patients with mild dependence wishing to reduce their alcohol consumption. Baclofen has a temporary indication in France, and may have a role in patients with co-morbid liver disease and anxiety, but its efficacy remains unproven.
\end{abstract}

\section{Keywords:}

Acamprosate, alcohol dependence, baclofen, chlordiazepoxide, disulfiram, nalmefene, naltrexone, relapse prevention, thiamine 


\section{Key Points}

-In all patients presenting in alcohol withdrawal, have a high index of suspicion of WernickeKorsakoff syndrome and a low threshold for treatment

- Relapse prevention medication should be considered in all patients with moderate to severe alcohol dependence as part of a detox plan

-Alcohol use disorders present in a wide range of acute and community medical settings, are frequently co-morbid with other physical and mental illnesses and require immediate management

-Medication for these patients is often suboptimal, leading to missed opportunities to improve health outcomes

\section{Management of alcohol withdrawal}

Patients presenting with symptoms of alcohol withdrawal require a quantified assessment of their alcohol use, including number of units of alcohol per day, duration of daily drinking, history of any previous seizures, and rating of severity of their alcohol withdrawal using a validated scale (e.g. revised Clinical Institute Withdrawal Assessment for Alcohol scale- CIWA-R) to assess the need for medically assisted detox (see Alcohol use disorders, pp xxx-xxx of this issue).

Unless a patient can be managed on a well-resourced unit where regular assessment of withdrawal symptoms can be undertaken, a fixed-dose reducing regimen of a benzodiazepine (diazepam or chlordiazepoxide) four times daily over 5-10 days is recommended over 'symptom-triggered' (as required) prescribing. ${ }^{1,2}$ Patients should not be started on a medically assisted detox in the community unless there is adequate provision for monitoring and a clear management plan for the maintenance of abstinence. In patients with severe liver disease, a shorter acting benzodiazepine that is not metabolized in the liver (e.g. oxazepam or lorazepam) may be safer to reduce risk of encephalopathy and sedation. It is important to monitor the response to ensure that patients are neither over-sedated nor under-treated. Patients should be made aware of the risks of taking benzodiazepines together with alcohol and encouraged to develop a collaborative plan for remaining abstinent at the end of the assisted withdrawal period.

Wernicke-Korsakoff syndrome, caused by acute-on-chronic thiamine (vitamin $\mathrm{B}_{1}$ ) deficiency, can present while a patient is still drinking or during withdrawal, so a presumed diagnosis in any alcohol-dependent patient with confusion is advised.1,2 Oral absorption of thiamine is low in this patient group; ensuring adequate doses of parenteral thiamine is a priority and is imperative before giving glucose infusions, which can cause Wernicke-Korsakoff syndrome in susceptible individuals. Oral thiamine $(100 \mathrm{mg}$ three times daily) should be continued for at least 6 weeks after detox until patients are eating normally (Table 1).

\section{Management of relapse prevention (Table2)}

After detox, as well as the behavioural and social adaptations that the patient should make to maintain abstinence from alcohol, neuroadaptation of the $\gamma$-aminobutyric acid (GABA) / glutamatergic systems continues as the brain adjusts to the alcohol free environment. As a result, patients can have heightened levels of anxiety and agitation, often leading to cravings for alcohol.

Acamprosate modulates the $N$-methyl-D-aspartate receptor and indirectly enhances GABA function; both of these are altered during alcohol withdrawal and the early stages of abstinence. Acamprosate is a first-line treatment and should be started by the end of detox to be most effective.

Naltrexone is an opioid antagonist, which acts indirectly to reduce craving, and has been 
found to be more effective in the prevention of return to heavy drinking than the maintenance of abstinence. It may therefore be the first-line choice in those who are unlikely to achieve abstinence immediately. Patients should be advised against the concomitant use of opioids. It has a better tolerability profile in men, and therefore should be started at a half dose (25 mg daily) in women.

Disulfiram acts by irreversible inactivation of acetaldehyde dehydrogenase (ALDH) enzymes in the liver. It is a second-line choice and should only be started by specialists in motivated patients who have had a thorough risk assessment. It takes approximately 5 days for new ALDH to be made, and patients are at risk of an aversive reaction to alcohol during this time. Earlier reports (in the 1950s) of it causing or worsening psychosis have not been seen since doses have been reduced to $200 \mathrm{mg}$ daily (from $2 \mathrm{~g}$ ). ${ }^{3}$ Patients taking disulfiram should be warned about the interaction between disulfiram and alcohol, which can manifest as flushing, nausea, palpitations and, more seriously, arrhythmias, hypertension and collapse. ${ }^{2}$

Nalmefene is another opioid antagonist, differing from naltrexone in that it is a partial agonist at the kappa $(\kappa)$ receptor. It has a licence for the reduction of alcohol consumption in individuals with mild dependence who do not need an immediate detox. It can be used on an 'as required' basis when patients fear they are at risk of drinking. It does not need to be started within specialist services and, as with the other medications, should be given alongside psychosocial support.

Baclofen is a GABA-B agonist, although its precise mechanism of action is not fully understood. It is excreted primarily unchanged by the kidney, but there appears to be significant inter-subject variation, and the therapeutic dosing window is not yet clear. Baclofen is a central nervous system depressant so there are potential concerns regarding overdose, but it may have a role in patients with severe liver disease and anxiety. ${ }^{3}$

Insert Table 12 here 
Table 1 Management of Wernicke-Korsakoff syndrome (WKS) ${ }^{4}$

Have a low threshold for treatment

Prophylactic treatment for patients at risk of WKS should be:

-One pair of i.m./i.v. ampoules of high-potency B-complex vitamins (Pabrinex ${ }^{\circledR}$ ) daily for 3-5 days

(Thiamine 200-300 mg i.m. daily can be given if Pabrinex® is unavailable)

Therapeutic treatment for presumed/diagnosed WKS consists of:

Gice 2-3 pairs of i.v. ampoules (i.e. 4-6 ampoules) of high-potency B-complex vitamins three times daily for 2 days

- If no response, discontinue treatment

- If signs/symptoms respond, continue one pair of i.v. or i.m. ampoules daily for 5 days or for as long as improvement continues

i.m., intramuscular; i.v., intravascular. 
Table 2 Medications licensed for use in the treatment of alcohol dependence

\begin{tabular}{|c|c|c|c|c|}
\hline Medication & $\begin{array}{l}\text { Standard } \\
\text { adult dose }\end{array}$ & Cautions & Duration & Main Use \\
\hline Acamprosate & $\begin{array}{l}666 \mathrm{mg} \text { (two } \\
\text { tablets) t.d.s }\end{array}$ & $\begin{array}{l}\text { Elderly patients, } \\
\text { renal insufficiency. } \\
\text { Check LFTs }\end{array}$ & $\begin{array}{l}6-12 \text { months. } \\
\text { Stop if relapse } \\
\text { of }>6 \text { weeks }\end{array}$ & $\begin{array}{l}\text { Maintenance of } \\
\text { abstinence }\end{array}$ \\
\hline Naltrexone & $50 \mathrm{mg}$ daily & $\begin{array}{l}\text { No concomitant } \\
\text { opioid use, reduced } \\
\text { tolerability in } \\
\text { women. Check LFTs }\end{array}$ & $\begin{array}{l}6-12 \text { months. } \\
\text { Stop if relapse } \\
\text { of }>6 \text { weeks }\end{array}$ & $\begin{array}{l}\text { Prevention of } \\
\text { relapse to heavy } \\
\text { drinking }\end{array}$ \\
\hline Disulfiram & $\begin{array}{l}200 \text { mg daily. } \\
\text { Can start } \\
\text { with loading } \\
\text { dose if } \\
\text { required }\end{array}$ & $\begin{array}{l}\text { Patient needs to be } \\
\text { aware of avoiding } \\
\text { alcohol in all } \\
\text { products (e.g. } \\
\text { perfume, } \\
\text { mouthwash). Risk } \\
\text { assessment } \\
\text { required. Improved } \\
\text { effectiveness if } \\
\text { 'witnessed' }\end{array}$ & $\begin{array}{l}\text { 6--12 months. } \\
\text { Stop } \\
\text { immediately on } \\
\text { resumption of } \\
\text { drinking }\end{array}$ & $\begin{array}{l}\text { Maintenance of } \\
\text { abstinence }\end{array}$ \\
\hline Nalmefene & $\begin{array}{l}18 \mathrm{mg} \text {, as } \\
\text { required, up } \\
\text { to once daily }\end{array}$ & $\begin{array}{l}\text { No concomitant } \\
\text { opioid use }\end{array}$ & Up to 6 months & $\begin{array}{l}\text { Reduction of } \\
\text { alcohol } \\
\text { consumption }\end{array}$ \\
\hline $\begin{array}{l}\text { Baclofen } \\
* \text { (therapeutic } \\
\text { dose not } \\
\text { established) }\end{array}$ & $\begin{array}{l}\text { Starting dose } \\
5 \text { mg t.d.s. } \\
\text { Doses above } \\
90 \text { mg daily } \\
\text { not advised * }\end{array}$ & $\begin{array}{l}\text { Serious respiratory } \\
\text { depression in } \\
\text { overdose, especially } \\
\text { with alcohol. } \\
\text { Potential for own } \\
\text { withdrawal } \\
\text { syndrome }\end{array}$ & Not established & $\begin{array}{l}\text { 'Temporary } \\
\text { recommendation } \\
\text { for use' in France } \\
\text { for maintenance of } \\
\text { alcohol abstinence }\end{array}$ \\
\hline
\end{tabular}

LFT, liver function test; t.d.s., three times daily. 


\section{KEY REFERENCES}

1. Lingford-Hughes AR, Welch S, Peters L, Nutt DJ; British Association for Psychopharmacology, Expert Reviewers Group. BAP updated guidelines: evidence-based guidelines for the pharmacological management of substance abuse, harmful use, addiction and comorbidity: recommendations from BAP. J Psychopharmacol 2012; 26: 899-952.

2. National Institute for Clinical Excellence. Alcohol-use disorders: diagnosis, assessment and management of harmful drinking and alcohol dependence. Clinical Guidance No. 115. London: NICE, 2011.

3. Sinclair JM, Chambers SE, Shiles CJ, Baldwin DS. Safety and tolerability of pharmacological treatment of alcohol dependence: comprehensive review of evidence. Drug Saf 2016; 39: 627-45.

4. Taylor DP, Paton C, Kapur S. The Maudsley prescribing guidelines in psychiatry, 12th edn. Wiley Blackwell, 2015. 